\title{
EGY KORA ÚJKORI TEMETŐ FELTÁRÁSA SZÉCSÉNYBEN
}

\author{
Líbor Csilla - Laczkó Virág - Zsiga-CsoltKó Emese - Balogh Bodor Tekia \\ Magyar Régészet 9. évf. (2020), 1. szám, pp. 30-34. doi: https://doi.org/10.36245/mr.2020.1.7
}

Szécsény belvárosában az elmúlt években jó néhány régészeti feltárásra került sor, amelyek elsösorban a középkori templomhoz kapcsolódtak, vagy a település nyomait, maradványait hozták felszinre. 2019 júliusában a Magyar Nemzeti Múzeum Régészeti Örökségvédelmi Igazgatósága megelözö feltárást végzett a Szécsény-Kossuth út 4. régészeti lelöhelyen. A lelöhely az egykori középkori várostól pár száz méterre délre található, a mai belvároshoz közel (1. kép). A feltárt több száz sír egy olyan korszak régészeti emlékeit mutatja be, amelyböl eddig kevés temetöt tártak fel, így a szécsényi megfigyelések, leletek messze túlmutatnak a helytörténeti jelentöségükön.

A temető feltárását többek között az tette lehetővé, hogy bár a város ezen része már körbeépült az évek során, ám a mostani ásatási területen nem épületek, hanem egy beton parkoló helyezkedett el. A lelőhely ennek ellenére bolygatott volt, a közmüvek korábbi kiépítése előzetes feltárások nélkül történt meg. Az 1800-as évek bolygatásairól szintén olvashatunk, de régészeti dokumentáció nincs róluk.

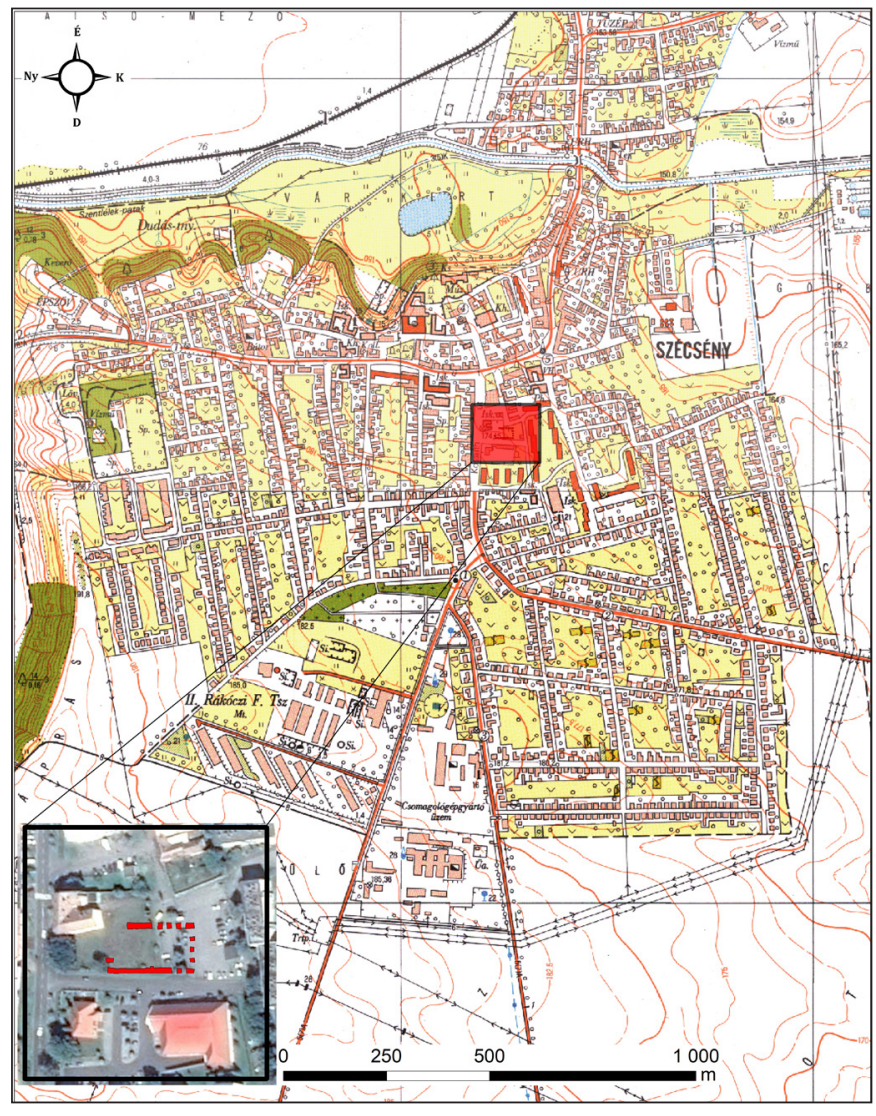

1. kép. Az ásatás területének elhelyezkedése Szécsényben

\section{A KUTATÁSTÖRTÉNET}

Elsőként - még az 1860-as években - Kubinyi Ferenc írt egy pinceásáskor előkerült temetőrészletről ezen a területen (GALCSIK, 2010, 158). A jelentésében több tárgyról is említést tett, melyeket a 16. századra keltezett, ezekről azonban más információ nem tudható (IPOLYI, 1963, 22). Az 1900-as évek végén további építkezések során újabb sírokat bolygattak meg; egy csecsemősírról Majcher Tamás részletesebben is írt (MAJCHER, 1993).

Megelőző feltárásra 2009-ben került sor a Kossuth Lajos-Sas utca sarkán épülő Penny Market áruház kivitelezése kapcsán. A Kubinyi Ferenc Múzeum végezte el az ásatást Zandler Krisztián vezetésével, melynek eredményeiről 2011-ben az ELTÉ-n egy szakdolgozat született Bercsényi Kinga tollából (BERCSÉNYI, 2011).

\section{A 2019-BEN FELTÁRT TEMETŐRÉSZLET}

A mi kutatásunk a lelőhely közepén, valamint a temető északkeleti végénél zajlott (2. kép). A mostani építkezés a kora újkori temetőt nem bolygatta meg a teljes felületén, régészeti szempontból csupán a 28 darab oszlophely területe volt érintett, amelyekre az általános iskolai tornacsarnokot építik majd a jövőben. Ezek körülbelül 240×350 cm-es, négyszögletes alapú, 2 méter mély pillérhelyek voltak.

2019-ben próbafeltárás zajlott a területen, melyet a Dornyay Béla Múzeum képviseletében Horváth Tünde régész végzett el. Mi 2019 júniusában 23 pillérhelyet tártunk fel, melynek során 286 sír- és 2 objektumszám került kiosztásra. Mindegyik pillérhelyen találtunk sírokat, melyek intenzitása változó volt. Az 


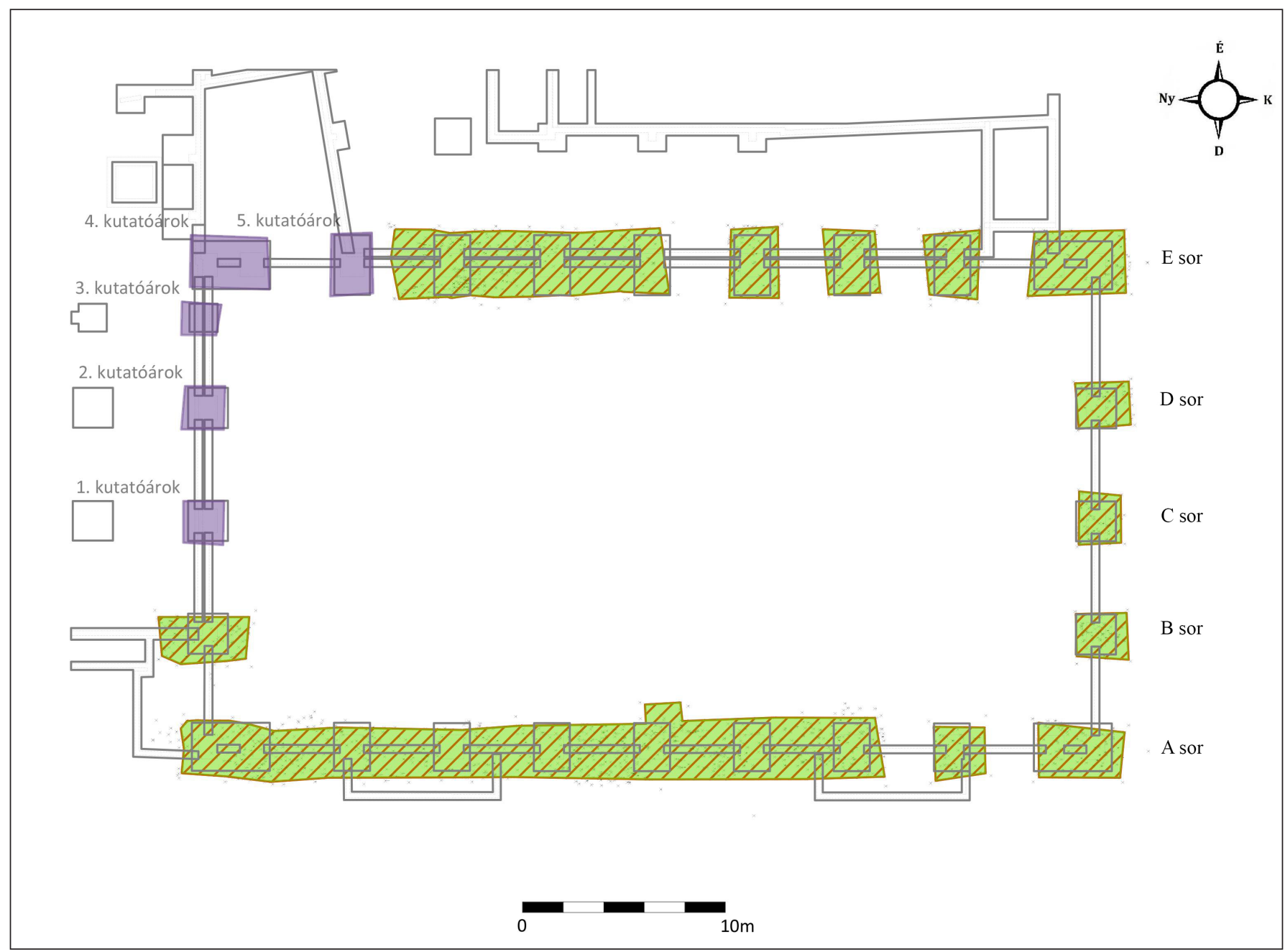

2. kép. A 2019-es ásatás a lelöhelyen. Lila szin: Horváth Tünde próbafeltárása 2019-ben; zöld szín: a MNM RÖG megelözö feltárása 2019-ben

„A” sorban elhelyezkedő pillérhelyekben akár 4-5 rétegben is összezsúfolódtak a sírok, míg az „E” sorban előfordult, hogy csupán 1-2 rétegben temetkeztek. A feltárás során bizonyossá vált, hogy a tornacsarnok egy kora újkori temetőre épül majd.

A sírok szinte mind NY-K-i tájolásúak, nagyon kis számban fordult elő ettől eltérés. A többrétegüségéből fakadóan a teljesen ép sírok száma viszonylag alacsony. Sok esetben egymást vágták a sírok, és emiatt lettek megbolygatva. Csak a felső rétegekben látható a nyoma annak, hogy egykor ezen a részen is állhattak házak, mivel itt nem voltak konkrét sírfoltok, csupán csonthalmokat, valamint szórványcsontokat találtunk.

A sírok nagy részénél a koporsó kiváló állapotban maradt meg, ezért a jövőben remélhetőleg az itt gyüjtött faminták elemzésére is sor kerül. Sikerült egy koporsófedél-maradványt majdnem teljesen egészben megtartanunk és felszednünk, amelyen a koporsó bronz szegecsekkel kialakított spirális díszítése figyelhető meg.

Bár a koporsók jó állapotban kerültek elő, körülbelül a sírok 80\%-ában a csontok rendkívül rossz megtartásúak voltak, és sokszor csupán csontporként maradtak meg. Egyelöre ismeretlen okból néhány esetben viszont jó állapotú, teljes csontvázakat sikerült feltárnunk. Felmerül a kérdés, hogy mivel magyarázható a csontok ilyen rossz megtartása (fa koporsó jelenléte, koporsó belső borítása, szécsényi föld kémiai hatása, városi környezet).

A kutatás jelenlegi fázisában a részletes antropológiai vizsgálatok még nem történtek meg, azonban a nagyszámú gyermeksír jelenléte jól illeszkedik a korszak temetőire jellemző halandósági képre (LíBOR, 2018). Mivel sajnos nem az egész temető került feltárásra - csak a pillérhelyekről vannak adataink -, ezért annak elemzési lehetőségei igen szükösek. 


\section{A LELETANYAG}

A temető leletanyagban gazdag, és megfelel a kora újkori jellegzetességeknek.

A feltárás során a 286 sírból 37 esetben sikerült pártára, vagy annak egykori jelenlétét igazoló leletre bukkannunk. Szórványként, illetve betöltésből további hat, eredetileg pártáról származó lelet is elökerült, melyek egyaránt tartozhattak a már azonosított vagy a még azonosítatlan darabokhoz. A párták néhány kivételtől eltekintve jellemzően jó megtartásúak (3. kép).

Öt sírban látszott egyértelmüen, hogy ún. bogláros pártát találtunk. Kilenc sírban fémfonalas fonatokkal díszített, keretező szegélyü pártára, illetve annak maradványaira leltünk. Két esetben a párta díszítését kizárólag a fémszálakból vert csipkék, fonatok adták, gyöngyöket, illetve egyéb díszítésre szolgáló szerelékeket nem fedeztünk fel. Az esetek többségében a pártákat különféle mintákat követve gyöngyökkel, flitterekkel, esetleg gránátköves szirmú virágokkal díszítették. Ezek közül kettőn ún. fémspirálok alkotta díszítéssel is találkozhattunk. Két sírban az előkerült párták egyedi kialakításúak voltak.

Ruházathoz köthetö leletek több sírban is megfigyelhetők. Három sírból került elő jó megtartású fémszálas textilből készített felsőruházat, amelyeket sikerült úgy felszednünk, hogy a jövőben - reményeink szerint - az egész ruházat rekonstrukciója megtörténhessen. További három alkalommal került elő lábbelihez tartozó bőrmaradvány, és a lábbeli fém alkatrészei. Ugyan szerves anyag nem köthető hozzájuk, ám 11 alkalommal figyelhető meg a ruházathoz tartozó párizsi kapcsok és gombok sorban való elhelyezkedése, melyek számos adattal szolgálnak a viselet rekonstruálásához (4. kép).

Több esetben találtunk ékszereket: hajtüket, gyürüket. Összesen $20 \mathrm{db}$ hajtü került elö, melyek végét a legtöbb esetben kisebb, valószínúleg díszítetlen gömbbel ékesítették, de elöfordult granulációval díszített, nagyobb gömbbel lezárt hajtű is. Különlegesnek számít az a két gránátberakásos, aranyozott ezüst hajtü, amely a 12. sírban a koponya két oldalánál került elő. A türész ezüstből készült, amelynek a végére ráhúzták a kocka alakú aranyozott ezüst, áttört, gránátberakásos fejet, melynek a tetején lévő virág szirmaiba forrasztottak egy kicsi ezüstgömböt (5. kép). A hajviselethez köthető továbbá egy nagy méretü hajcsat, illetve egy kontytü, melynek a kör alakú alapja és türésze került elő.

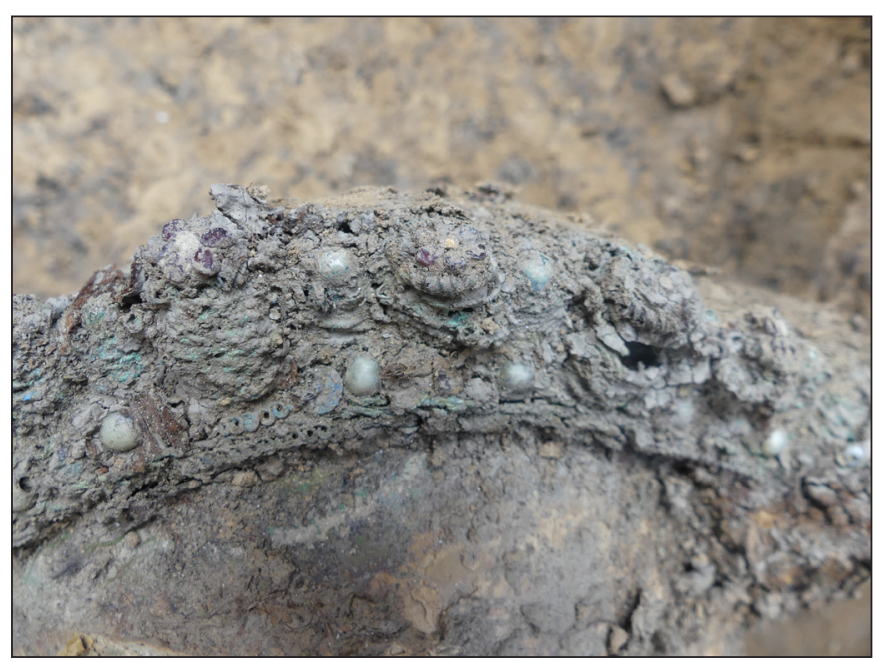

3. kép. A 205. sir bogláros pártájának részlete

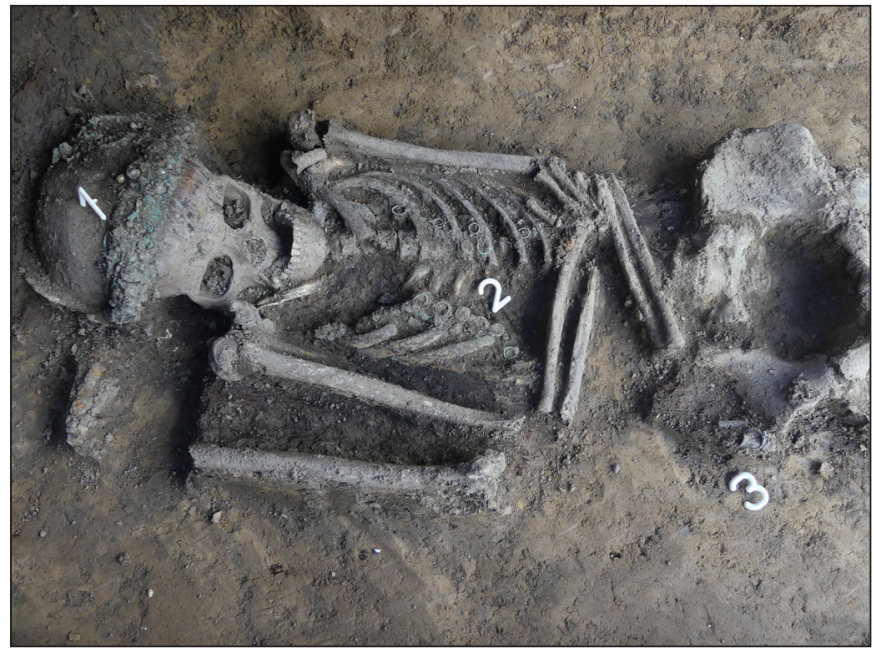

4. kép. A 259. sír. Mellékletek: 1: párta; 2: füzöhöz tartozó fémkarikák; 3: négykarmos foglalatos gyürü

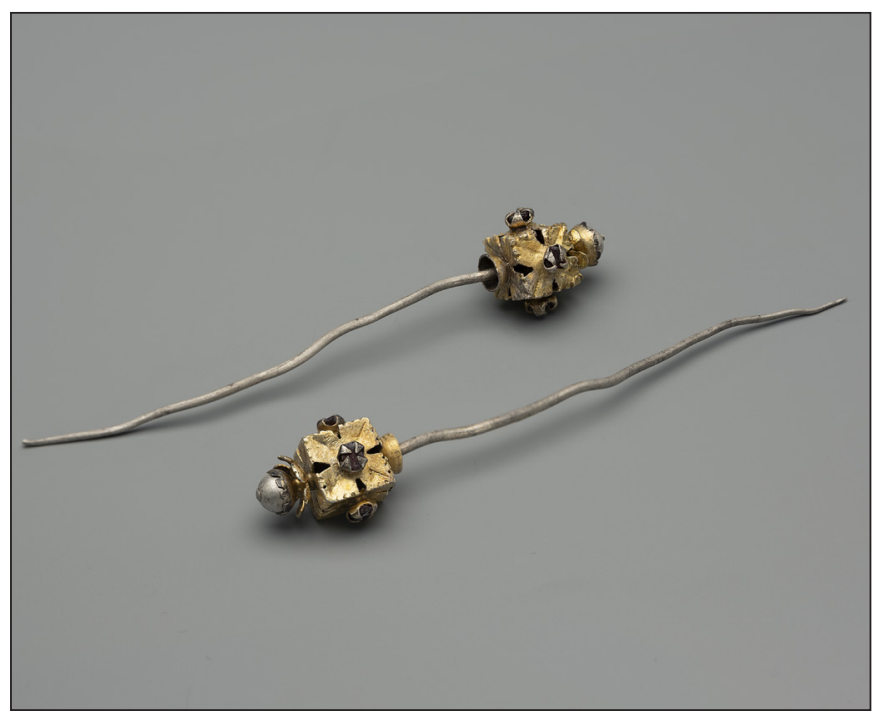

5. kép. Aranyozott ezüst, gránátberakásos hajtü, 12. sír (Fotó: Bicskei József) 
Líbor Csilla-Laczkó Virág-Zsiga-Csoltkó Emese-Balogh Bodor Tekla • Egy kora újkori temetö feltárása Szécsényben

A gyürük közül egyszerü nemesfém karikákat találtak a sírokban, valamint egy-egy gondosabban elkészített darab is előkerült. A leletanyag egyik legszebb darabja egy aranyozott ezüst, öntött, valószínűleg gránátberakásos gyürű (6. kép). Az ékszer fején négykarmos, tokos foglalatban csiszolt gránátberakás helyezkedik el, foglalatonként egy-egy levéldíszítéssel. Szimmetrikusan öt ovális alakú csüngő kapcsolódik a gyürühöz, melyek végén szintén négykarmos foglalatban található gránátberakás. Sajnos az egyik csüngő korábban elveszett.

Számos lelet köthető a keresztény vallásossághoz: rózsafüzérek, ólomkeresztek és kegyérmék is előkerültek a sírokból. Kiemelkedően érdekes lelet is előkerült: egy aranyozott, belül csontmerevítővel ellátott medál. A feltárás során a medál sajnos szétnyílt, ám így láthatóvá vált egy apróra összehajtogatott, német nyelvü, nyomtatott bibliarészlet (7. kép).

A temető pontosabb datálásában segíthetnek majd az előkerült érmék, melyeket föleg gyermeksírokba helyeztek. Sajnos az erős korrodálódás miatt ezek azonosítása a helyszínen - restaurálás elött - nem valósulhatott meg. A korábbi kutatási eredményekkel összhangban (BERCSÉNYI, 2011, 52-54) inkább a kora újkorra datálható temető került elő ezen a területen. Mivel a városban történő temetkezés Mária Terézia ideje alatt megszünt, a temető keltezése ennél korábbra tehető. Úgy látszik, hogy annak használata viszont egészen az 1700-as évek közepéig tartott.

Találtunk néhány kimeszelt aljú sírt is, és mivel a területen az 1680-as évekböl van tudomásunk nagyobb pestis-, illetve egyéb járványokról, ezért valószínüleg ebben az időben a temető már használatban volt. Ugyan nem történt meg a leletek feldolgozása, de a mostani eredményeink alapján az 1600-as évek végére és az 1700-as évek első felére datálható ez a temetőrészlet.

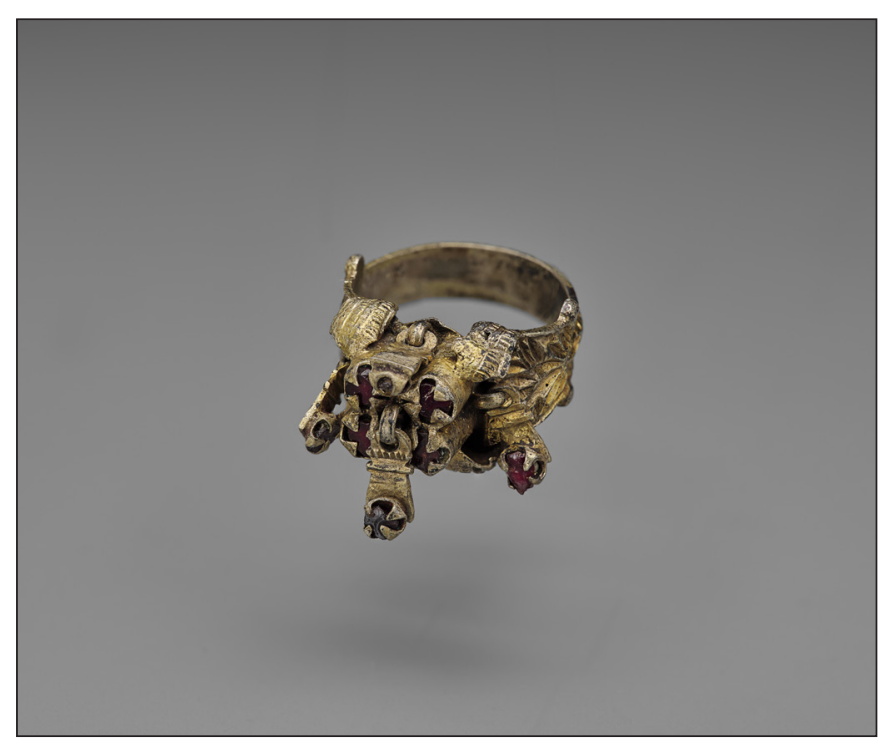

6 kép. Aranyozott ezüst, gránátberakásos, csüngös gyürü, 44. sir (Fotó: Bicskei József)

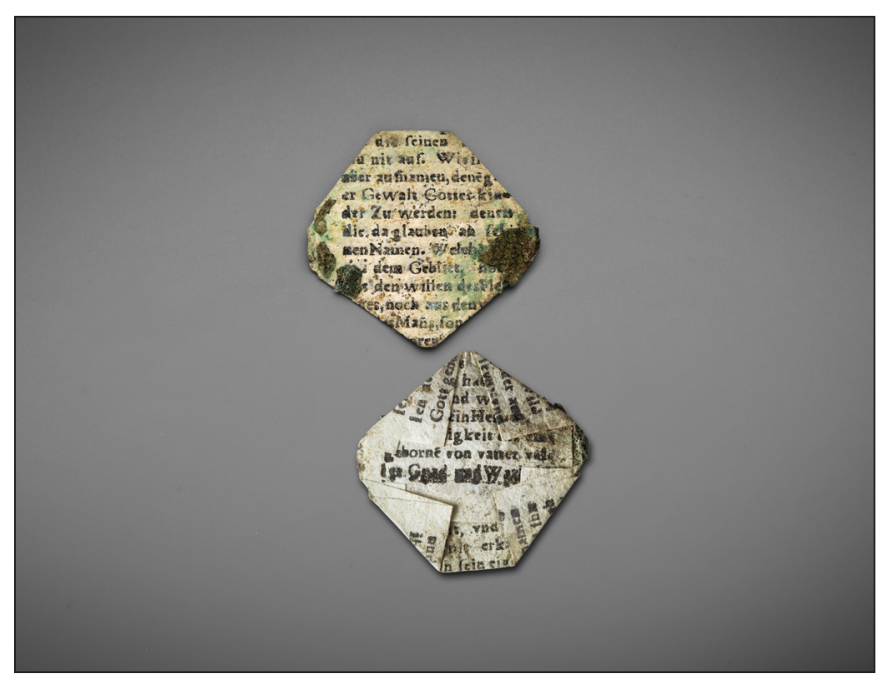

7 kép. A medálból elökerült német nyelvü, nyomtatott bibliarészlet (Fotó: Bicskei József. Mai magyar forditásban: „,... a saját világába jött, de az övéi nem fogadták be öt. Akik pedig befogadták, azoknak hatalmat adott arra, hogy Isten gyermekeivé legyenek; mindazokat, akik hisznek az ö nevében, akik nem vérböl, sem a test, sem a férfi akaratából, hanem Istentöl születtek." (János 1, 11-13.)

\section{ÖSSZEFOGLALÁS}

Összességében a temetőrészlet leletanyagban gazdag, és azok többsége igen szép állapotban maradt meg. Úgy véljük, hogy a szécsényi temető feldolgozása kiemelkedő információkat adhat hozzá a korszak eddigi kutatástörténetéhez.

Korábban a temető sürüsödését a 2009-es ásatás területén feltételezték, míg azonban a 2009-es ásatás

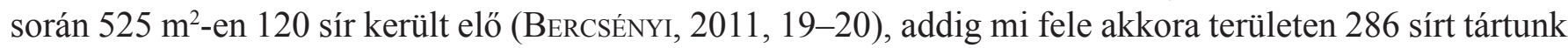
fel. Ez a különbség abból is adódhat, hogy eltérő szempontok szerint osztottuk ki a sírszámokat, hiszen mi sok esetben az egyedül álló koponyáknak, illetve az üres síroknak is külön számot adtunk.

A temető kiterjedése feltehetően nem ér véget ott, ahol a kivitelezés zajlott annak ellenére, hogy ritkulás vehető észre a terület északkeleti sarka felé haladva. A korábbi emlékek alapján a mostani ásatási helyszín- 
Líbor Csilla - Laczkó Virág - Zsiga-Csoltkó Emese-Balogh Bodor Tekla • Egy kora újkori temetö feltárása Szécsényben

töl körülbelül 100 méterrel északabbra, a Palóc Áruház alatt csontokat találtak, ami feltételezi, hogy ebben az irányban akár idáig is kiterjedhetett a temető (BERCSÉNYI, 2011, 18). A sürübb részek egyértelmüen a mostani ásatástól délre helyezkedhettek el a mai Penny Market áruház épületének irányába. Nyugat felé valószínüleg a Kossuth utca jelentette a temető végét. Déli irányban Zandler Krisztiánék kutatása alapján, Bercsényi Kinga szerint a Magyar utcáig terjedhetett a temető (BERCSÉNYI, 2011, 17-21).

\section{KÖSZÖNETNYILVÁNÍTÁS}

Köszönetet mondunk Sebe Krisztiánnak (Jánosik Kft.), Horváth Tündének, valamint Guba Szilviának (Kubinyi Ferenc Múzeum).

\section{AJÁNLOTT IRODALOM}

Lengyel, B. (2019). Pártás kislány a hódoltság korából. A gödöllői párta rekonstrukciója [Fetița cu cunună din epoca ocupației otomane. Reconstrucția cununii din Gödöllö]. Erdélyi Magyar Restaurátor Füzetek 19, $19-26$.

Mérai, D. (2008). Ethnic and social aspects of clothing: The archaeological evidence in Early Modern Hungary. Annual of Medieval Studies at the CEU 14, 81-107.

Mérai, D. (2010). "The True and Exact Dresses and Fashion": Archaeological Clothing Remains and their Social Contexts in Sixteenth- and Seventeenth-century Hungary. Archaeolingua Central European Series 5. Budapest: Archaeolingua.

Ritoók, Á. \& Simonyi, E. (2005). „... a halál árnyékának völgyében járok”: A középkori templom körüli temetök kutatása. Opuscula Hungarica 6. Budapest: Magyar Nemzeti Múzeum.

Zay, O. (2015). „Tegnap még lány vala, most immár kontya vagyon”: Női haj- és fejviseletek a kora újkorban [,Gestern was sie Mädchen, jetzt trägt sie nummehr einen Dutt”: Haar- und Kopftrachten der Frauen in der Frühneuzeit]. In Szőllősy Cs. \& Pokrovenszki K. (szerk.), Fiatal Középkoros Régészek VI. Konferenciájának Tanulmánykötete (pp. 205-222). Székesfehérvár: Szent István Király Múzeum.

\section{BiBLIOGRÁFIA}

Bercsényi, K. (2011). Szécsény kora újkori temetője (Szakdolgozat). Eötvös Loránd Tudományegyetem, Budapest.

Galcsik, Zs. (2010). Kubinyi Ferenc jelentése az 1862-ben Szécsényben és környékén talált régiségekről. In Szenográdi F. (szerk.), Szécsényi kalendárium a 2010-es esztendőre. Szécsény.

Ipolyi, A. (1863). Magyar régészeti Krónika. Archaeologiai Közlemények 3, 169-179.

Líbor, Cs. (2018). Mit mesélnek nekünk a gyermeksírok? Balatonszárszó-Kis-erdei-dülő középkori temetőjének példája alapján [What's the story of children from medieval times?]. In Ringer, I. (szerk.), $A$ Fiatal Középkoros Régészek VIII. Konferenciájának Tanulmánykötete (pp. 95-107). Sátoraljaújhely: Petőfi Irodalmi Múzeum - Kazinczy Ferenc Múzeum.

Majcher, T. (1993). Szécsény közigazgatási egység középkori régészeti topográfiája (Szakdolgozat). Eötvös Loránd Tudományegyetem, Budapest. 